\title{
The Fate of Atrazine in Tropical Environments: Photolysis, Acute Toxicity and Endocrine Disruptor Potential
}

\author{
Polyana S. Barcellos, ${ }^{a}$ Thiago M. R. Araújo, ${ }^{b}$ Giselle Gomes, ${ }^{c}$ Daniele M. Bila ${ }^{c}$ and \\ Maria Cristina Canela ${ }^{\circledR} *, a$
}

\author{
${ }^{a}$ Grupo de Pesquisa em Química Ambiental (GPQA), \\ Universidade Estadual do Norte Fluminense Darcy Ribeiro, \\ 28013-602 Campos dos Goytacazes-RJ, Brazil
}

${ }^{b}$ Laboratório de Análise e Monitoramento das Águas (LabFoz), Instituto Federal Fluminense, 28080-565 Campos dos Goytacazes-RJ, Brazil

'Laboratório de Engenharia Sanitária, Universidade Estadual do Rio de Janeiro, 20261-232 Rio de Janeiro-RJ, Brazil

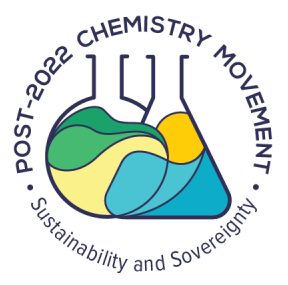

\begin{abstract}
Triazine herbicides are widely used both in Brazil and internationally and are frequently detected in natural environments and drinking water. This study assesses atrazine degradation through solar radiation under tropical conditions and determines the toxicity of the intermediates. Atrazine degradation is tested through ultrapure water, humic acid solution and natural water experiments, with exposure to sunlight to simulate a natural environment. A yeast estrogen screen (YES) assay and Artemia salina test are carried out during the abiotic degradation. The atrazine degradation depends on the radiation intensity, since the experiments conducted in the summer reached 50\% after ca. 17 days. No significant variations in this herbicide concentration are observed after 90 days of exposure in the fall. Atrazine degradation is observed only in humic acid and is responsible for indirect photolysis. Intermediates, namely, desethylatrazine (DEA) and deisopropylatrazine (DIA), are identified and quantified at the $\mu \mathrm{g} \mathrm{L}^{-1}$ level. Thus, with the degradation of atrazine in water, the medium toxicity may decrease, since DEA and DIA have mean effective concentrations that kill $50 \%$ of Artemia salina $\left(\mathrm{EC}_{50}\right)$ similars to atrazine $\left(13 \mathrm{mg} \mathrm{L}^{-1}\right)$. No estrogenic activity in the YES is detected for atrazine and its metabolites. These findings evidence that radiation intensity and organic substances in tropical countries influence the half-life of pesticides in aquatic environments.
\end{abstract}

Keywords: atrazine degradation, photolysis, yeast estrogen-inducible expression system, Artemia salina, humic substances

\section{Introduction}

The use of chemical compounds for insect pest control and food crop protection has been a common practice for centuries. These compounds are used to kill or control undesirable organisms. ${ }^{1}$ Global pesticide consumption was ca. 4 million tons in 2019 , equivalent to $0.6 \mathrm{~kg}$ per person, and the use per area of cropland has increased from 1.8 to $2.7 \mathrm{~kg} \mathrm{ha}^{-1}$. The largest consumer of pesticides in the world is China (1,774 kt), with the United States (USA) in second (408 kt) and Brazil in third (377 kt). ${ }^{2}$ In Brazil, the pesticide use per cropland area is $5.94 \mathrm{~kg} \mathrm{ha}^{-1}$, higher

*e-mail: mccanela@uenf.br

Editor handled this article: Teodoro S. Kaufman than the US with the largest cropland area $\left(2.54 \mathrm{~kg} \mathrm{ha}^{-1}\right)$ or India $\left(0.34 \mathrm{~kg} \mathrm{ha}^{-1}\right){ }^{3}$

Only $0.1 \%$ of the total amount applied reaches the target during pesticide application, while the remainder, $99.9 \%$, displays the potential to transfer to other environmental compartments, such as surface and groundwater. ${ }^{4}$ Herbicides are the most applied pesticide class in Brazil and the US. Atrazine (ATZ) is the second most used herbicide in the US and is used for corn crops at an $86 \%$ frequency rate. About $75 \%$ of the cornfield areas in the US are treated with ATZ. ${ }^{5}$ In Brazil, ATZ is used for sugarcane and corn crops and was the sixth most sold active ingredient in Brazil in 2017 , totaling 24,730 tons. $^{6}$

ATZ is the most commonly detected pesticide in surface waters. Its frequent detection in streams, rivers, 
groundwaters and reservoirs is directly related to the high volumes applied and its propensity to persist in soils and move with water. ${ }^{7-10}$ ATZ has a moderate toxicological level to human and aquatic health and has been banned in the European Union since 2003., ${ }^{3,11}$ There is a relationship between the use of this substance and several effects, such as amphibian feminization, ${ }^{11}$ ovulatory cycle irregularity in women ${ }^{12}$ and decreased male fertility in men living in agricultural areas, ${ }^{13}$ have been reported.

The main methods of removing atrazine from the environment are through biotransformation and phototransformation, which produce several intermediates. ${ }^{14}$ In soil, the ATZ half-life is from 1.5 months to 5 years and the primary decomposition process is biotic, producing metabolites that are more soluble in water. During the degradation process, ATZ can produce metabolites, including desethylatrazine (DEA), deisopropylatrazine (DIA) and 2-hydroxyatrazine, ${ }^{15}$ with different levels of toxicity and solubility. The high and moderate solubility of these metabolites and ATZ, respectively, increases their leaching into aquatic bodies, thereby changing the halflife of these contaminants in the environment. According to Lartiges and Garrigues, ${ }^{16}$ triazine herbicides are stable at room temperature, neutral $\mathrm{pH}$ and in absence of light, microorganisms and humic substances (HS). In contrast, other natural conditions are important in determining the fate of atrazine in the environment. Studies with HS and other abiotic catalysts have proposed a transformation mechanism from the hydrogen bond between the ring nitrogen of triazine and the carboxylic group, resulting in other metabolites. ${ }^{17}$ Therefore, $\mathrm{pH}$ is another important parameter in the degradation of the triazines in water because it favors the hydrolysis process at $\mathrm{pH}<6$, which changes the surface protonation of HS and biotic degradation..$^{18}$

Finally, the ATZ transformations in aquatic systems mediated by sunlight take place by two processes: direct and indirect photolysis. In direct photolysis, the degradation of the compound occurs because it absorbs solar radiation. This direct energy absorption can, for example, result in bond cleavage, dimerization or rearrangement in the chemical structure of the pesticide. As the ozone layer absorbs radiation from the Sun with a wavelength less than $290 \mathrm{~nm}$, compounds that do not have absorption at wavelengths higher than this do not undergo direct photolysis in these environments, i.e., this type of process is dependent on the absorption spectrum of the pesticide. ${ }^{19,20}$ In indirect photolysis, the absorption of radiation by another compound present in the medium (sensitizer) results in the degradation of the pollutant. In a possible situation, the excited compound transfers energy or electrons to the pesticide, which may undergo some processes, such as homolysis, heterolysis or photoionization. ${ }^{21}$ In another situation, compound excitation results in the formation of reactive species, which initiate a series of reactions that lead to pesticide degradation. ${ }^{19,20}$ Figure 1 represents these possible paths.

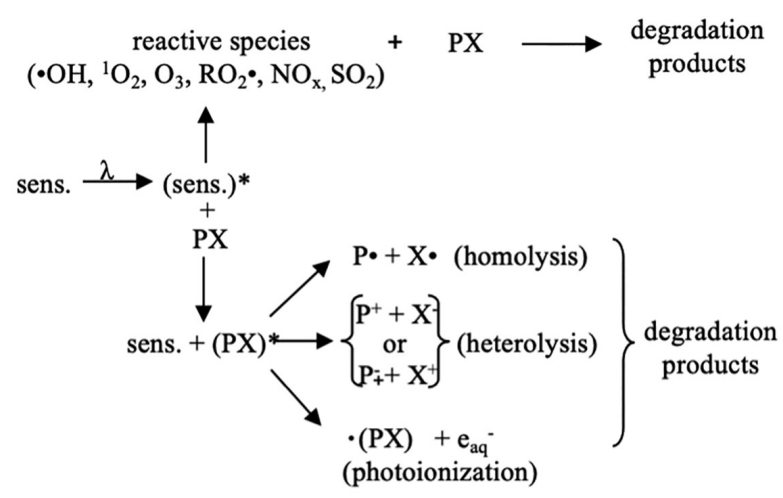

Figure 1. Pathways for pesticide degradation via indirect photolysis. sens.: sensibilizer; PX: pesticide (adapted from Burrows et al..$^{21}$ and Mansour et al..$^{19}$ ).

Although some metals, such as iron, can act as photosensitizers in the formation of reactive species for the degradation of various pesticides, HS are the main ones studied because they are present in large quantities in soil and freshwater. ${ }^{19,20}$ Phototransformation studies of ATZ in natural waters studied by Konstantinou et al..$^{22}$ showed that the degradation rate was lower than through direct photolysis and attributed this to the competition of the HS or the particulate material suspended by the irradiation. In contrast, other authors ${ }^{21,23,24}$ have showed that the presence of HS increases the phototransformation rate due to photosensibilization.

Few studies have assessed the fate of ATZ in these ecosystems in a more realistic manner ${ }^{15,18,25,26}$ and none have considered Southern Hemisphere climatic conditions. Most previous evaluations used artificial radiation ${ }^{27,28}$ and pure active ingredients ${ }^{16,18,25}$ and were carried out in the Northern Hemisphere. ${ }^{16,18,25}$ In contrast, this study assesses the photolysis of ATZ under tropical conditions (southeastern Brazil) in ultrapure water, a humic acid solution and natural waters using its commercial formulation. Toxicity studies are also carried out during the degradation process through a yeast expression system with an estrogen-induced test (YES) and an Artemia salina assay.

\section{Experimental}

\section{Reagents}

The pesticide and its intermediates were purchased from Sigma-Aldrich (St. Louis, USA) namely, atrazine 
(98.8\% purity), desethylatrazine (DEA) (99.5\% purity) and deisopropylatrazine (DIA) (97.5\% purity). The commercial formulation used herein was $\operatorname{Siptran}^{\circledR}\left(500 \mathrm{~g} \mathrm{~L}^{-1}\right)$ (SIPCAMNICHINO-Oxon, São Paulo, Brazil).

Solvents, namely, ethyl acetate (99.8\% purity), methanol (99.9\% purity), ethanol (99.9\% purity) and acetone (99.5\% purity), all gas chromatography grade, were purchased from Tedia Brasil (Rio de Janeiro, Brazil). Anhydrous sodium sulfate (99\% purity) and sodium hydroxide ( $85 \%$ purity) were purchased from Vetec (Rio de Janeiro, Brazil). The humic acid sodium salt was obtained from Sigma-Aldrich (Steinheim, Germany) and sulfuric acid (98\% purity) was purchased from Synth (Diadema, Brazil).

The glasswork was washed with distilled water (obtained from a Buchi distiller), Extran 3\% (Merck, Rio de Janeiro, Brazil) and ultrapure type I water (obtained by a Milli-Q plus system, Millipore, Mississauga, Canada), followed by drying at $100{ }^{\circ} \mathrm{C}$ in a drying and sterilizing oven (Solab, SL-100, 110 V, Piracicaba, Brazil) before use.

\section{ATZ degradation in natural water and humic acid solution}

ATZ degradation experiments under sunlight were carried out in Campos dos Goytacazes (21 ${ }^{\circ} 45^{\prime} 16^{\prime \prime} \mathrm{S}$, $\left.41^{\circ} 19^{\prime} 28^{\prime \prime} \mathrm{W}\right)$. The experiments were performed according to the procedure proposed by Araújo et al..$^{23}$ Three experiments were performed, each lasting 90 days. Two were performed with ultrapure type I water and a humic acid (HA) solution in the fall of 2015 and the summer of 2017. The third was performed using water from the Paraíba do Sul River during the summer of 2018. This river is a crucial aquatic system in southeast Brazil and its drainage basin is ca. $62,074 \mathrm{~km}^{2} .^{29}$

The HA solution of neutral $\mathrm{pH}$ was prepared based on the US Environmental Protection Agency (US EPA) protocol for indirect photolysis tests. ${ }^{30}$ First, $20 \mathrm{~g}$ of HA were added into $2 \mathrm{~L}$ of a $0.1 \%$ sodium hydroxide solution and allowed to stir for $1 \mathrm{~h}$. After this period, the solution $\mathrm{pH}$ was adjusted to 7 by adding $9 \mathrm{~mol} \mathrm{~L}^{-1}$ sulfuric acid. The solution was then filtered (qualitative filter, Whatman No. 1) and exposed to sunlight for 4 days. After the exposure, $5.5 \mathrm{~mL}$ of aliquot were removed to prepare a $1 \mathrm{~L}$ HA stock solution. This solution had an absorbance of 0.537 a.u. at $370 \mathrm{~nm}$, determined using a UV-Vis spectrophotometer (Agilent/Varian Cary ${ }^{\circledR}$ 50, Barueri, Brazil), and was later stored under refrigeration. Before preparing the ATZ solutions with HA used in the degradation experiments, the HA stock solution was diluted ten times with a $0.01 \mathrm{~mol} \mathrm{~L}^{-1}$ phosphate buffer to generate a solution with an absorbance of 0.0537 a.u. at $370 \mathrm{~nm}$.

A natural water sample was collected from the Paraíba do Sul River in Campos dos Goytacazes for the third experiment. This sample was filtered through an $11 \mathrm{~mm}$ qualitative filter (Whatman No. 1) and separated into two parts: natural water for direct use in the experiment and another autoclaved at $120^{\circ} \mathrm{C}$ and $1.1 \mathrm{~atm}$ for $20 \mathrm{~min}$. Some physicochemical properties of this natural water are displayed in Table 1.

All aqueous matrices used in the experiments contained an ATZ concentration (from commercial formulation) of ca. $1.25 \mathrm{mg} \mathrm{L}^{-1}$. The actual ATZ concentration in the commercial formulation was determined by gas chromatography before these procedures.

The prepared solutions were packaged for each experimental set without any headspace in borosilicate flasks (40 mL, Wheaton, Millville, US). Light attenuation by the glass was $14 \%$ at $320 \mathrm{~nm}, 21 \%$ at $310 \mathrm{~nm}, 32 \%$ at $300 \mathrm{~nm}, 52 \%$ at $290 \mathrm{~nm}$ and $74 \%$ at $280 \mathrm{~nm}$.

The flasks were then exposed to solar radiation according to the procedure proposed by Araújo et al..$^{23}$ For temperature control, the flasks were immersed in a $1000 \mathrm{~L}$ water container (swimming pool), protected (covered with aluminum foil) from sunlight or exposed by the irradiation (Figure S1, Supplementary Information (SI) section). Two thermometers (Incoterm, Rio Grande do Sul, Brazil) were used to determine the maximum and minimum temperatures during the experiments, inside and outside of the water container. The air temperature and solar radiation intensity averages were obtained from a National Institute

Table 1. Selected Paraíba do Sul River water physicochemical properties, in natura (iRW) and autoclaved (aRW), before and after atrazine (ATZ) addition

\begin{tabular}{lccccc}
\hline \multirow{2}{*}{ Parameter } & \multicolumn{2}{c}{ iRW } & & \multicolumn{2}{c}{ aRW } \\
\cline { 2 - 3 } \cline { 5 - 6 } & with ATZ & without ATZ & 7.10 & with ATZ & without ATZ \\
\hline $\mathrm{pH}$ & 7.31 & 8.20 & 8.26 & 9.36 \\
$\mathrm{DO} /\left(\mathrm{mg} \mathrm{L}^{-1}\right)$ & 8.10 & 66.98 & 8.00 & 8.10 \\
Conductivity / $\left(\mu \mathrm{S} \mathrm{cm}^{-1}\right)$ & 68.27 & 25 & 84.00 & 86.15 \\
Turbidity / NTU & 24 & 144.7 & 30 & 32 \\
Color $^{31} /\left(\mathrm{mgPt}^{-C o ~ L} \mathrm{~L}^{-1}\right)$ & 133.4 & & 184.5 & 193.5 \\
\hline
\end{tabular}

DO: dissolved oxygen; NTU: nephelometric turbidity unit. 
Table 2. Meteorological conditions during experiments

\begin{tabular}{|c|c|c|c|c|c|}
\hline \multirow{2}{*}{$\begin{array}{l}\text { Experiment/exposure } \\
\text { date and season }\end{array}$} & \multicolumn{2}{|c|}{$\begin{array}{l}\text { Average minimum and maximum temperature } \\
\text { (standard deviation })^{\mathrm{a}} /{ }^{\circ} \mathrm{C}\end{array}$} & \multirow{2}{*}{$\begin{array}{l}\text { Average air } \\
\text { temperature }{ }^{\mathrm{b}} /{ }^{\circ} \mathrm{C}\end{array}$} & \multirow{2}{*}{$\begin{array}{c}\text { Average irradiation }{ }^{\mathrm{b}} \\
\text { (maximum in period) } / \\
\left(\mathrm{W} \mathrm{m}^{-2}\right)\end{array}$} & \multirow{2}{*}{$\begin{array}{c}\text { Average } \\
\text { precipitation } / \mathrm{mm}\end{array}$} \\
\hline & $\begin{array}{c}\text { Inside } \\
\text { (water bath) }\end{array}$ & $\begin{array}{l}\text { Outside } \\
\text { (air) }\end{array}$ & & & \\
\hline \multirow{2}{*}{$\begin{array}{l}04 / 23 / 2015 \text { to } 07 / 22 / 2015 \\
\text { (mostly fall) }\end{array}$} & $20.6(1.7)$ & $20.0(2.9)$ & \multirow{2}{*}{22.0} & \multirow{2}{*}{142.8} & \multirow{2}{*}{0.0898} \\
\hline & $28.0(2.1)$ & $33.1(2.6)$ & & & \\
\hline \multirow{2}{*}{$\begin{array}{l}\text { 01/05/2017 to } 04 / 05 / 2017 \\
\text { (mostly summer) }\end{array}$} & 23.4 (1.6) & $30.1(3.8)$ & \multirow{2}{*}{26.4} & \multirow{2}{*}{278.7} & \multirow{2}{*}{0.0916} \\
\hline & $34.1(2.3)$ & $38.8(3.1)$ & & & \\
\hline \multirow{2}{*}{$\begin{array}{l}\text { 01/11/2018 to } 04 / 11 / 2018 \\
\text { (mostly summer) }\end{array}$} & $25.6(3.6)$ & $25.6(3.1)$ & \multirow{2}{*}{26.1} & \multirow{2}{*}{268.7} & \multirow{2}{*}{0.277} \\
\hline & $26.7(3.1)$ & 36.7 (3.6) & & & \\
\hline
\end{tabular}

average, maximum and minimum temperatures obtained using thermometers (Incoterm, Rio Grande do Sul, Brazil); ${ }^{\mathrm{b} a v e r a g e}$ air temperature and average irradiation obtained from National Institute of Meteorology (INMET) weather station (A607), located in Campos dos Goytacazes (2142’53”S, 41²0’38’W).

of Meteorology (INMET) weather station (A607), located

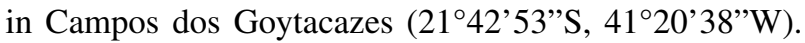
The pyranometer present in this station was the CM 6B (Kipp \& Zonen B.V., Delft, Netherlands), with a spectral range of measurements of 310-2800 nm. Table 2 lists the climatic conditions monitored throughout the exposure for each experiment.

With an appropriate analytical method, the ATZ concentrations were determined in triplicate, initially and after 4, 8, 12, 21, 28, 39, 48, 61, 75 and 90 days of exposure.

\section{Sample analysis}

Extractions of ATZ and its degradation products, DEA and DIA, were performed by solid-phase extraction (SPE) by filtering $25 \mathrm{~mL}$ of each sample and subsequently eluting with three $2.5 \mathrm{~mL}$ ethyl acetate aliquots. The extracts were then evaporated to dryness and resuspended in $300 \mu \mathrm{L}$ of the same solvent. SPE columns (SampliQ OPT, $60 \mathrm{mg}$ per $3 \mathrm{~mL}$ ) and a manifold, both from Agilent Technologies (Santa Clara, US), polytetrafluoroethylene stoppers and tubes, were used for this step. A rotary evaporator with a heating bath (Fisatom, model 550, series 1033810, 115 V, 60 Hz, 1200 W, São Paulo, Brazil) and argon flow (5.0, Air Liquid, Macaé, Brazil) was used to concentrate the samples.

The analyses were performed on a gas chromatograph coupled to a mass spectrometer (GC-MS 2010-Plus system, Shimadzu, Kyoto, Japan) operating with an electron impact ionization source. A VF-5 ms (5\% phenyl polysiloxane) capillary column (Varian, Palo Alto, USA), with a $30 \mathrm{~m}$ length, an internal diameter of $0.25 \mathrm{~mm}$ and a film thickness of $0.25 \mu \mathrm{m}$, was used. The oven temperature program was set at an initial temperature of $100{ }^{\circ} \mathrm{C}$, followed by a heating rate of $25^{\circ} \mathrm{C} \mathrm{min}-1$ to $250{ }^{\circ} \mathrm{C}$ and $15{ }^{\circ} \mathrm{C} \mathrm{min}^{-1}$ to $300{ }^{\circ} \mathrm{C}$. The total program time was 9.33 min. Helium was used as a carrier gas $\left(17 \mathrm{~mL} \mathrm{~min}^{-1}\right)$ at a constant pressure of $203 \mathrm{kPa}$. The injector temperature and volume used were $240{ }^{\circ} \mathrm{C}$ and $1 \mu \mathrm{L}$, respectively.

The general mass spectrometry working conditions were an ionization energy of $70 \mathrm{eV}$ and interface and ion source temperatures of 200 and $230{ }^{\circ} \mathrm{C}$, respectively. The retention time and mass spectra of the target compounds were confirmed through the electronic ionization scan mode ( $\operatorname{scan} m / z, 60-600$ and a 3 min solvent delay). Selected ion monitoring (SIM) mode was used to detect lower concentrations for quantification. Table 3 summarizes the retention times and selected ions in SIM mode for each analyzed substance.

Table 3. Ions selected for SIM analysis and ATZ, DEA and DIA retention times $\left(t_{R}\right)$

\begin{tabular}{lcc}
\hline Compound & Ions $(m / z)$ & $\mathrm{t}_{\mathrm{R}} / \min$ \\
\hline ATZ & $173,200,{ }^{\mathrm{a}} 215$ & 4.935 \\
DEA & $145,172,{ }^{\mathrm{a}} 187$ & 4.508 \\
DIA & $145,158,173^{\mathrm{a}}$ & 4.460 \\
\hline
\end{tabular}

${ }^{a}$ Most abundant fragment. SIM: selected ion monitoring; ATZ: atrazine; DEA: desethylatrazine; DIA: deisopropylatrazine.

The analytical curves of the ATZ, DEA and DIA standards were completed for all matrices (type I ultrapure water, HA solution and natural river water) and prepared at 1.30, 1.00, 0.70, 0.40 and $0.10 \mathrm{mg} \mathrm{L}^{-1}$ concentrations. For DIA and DEA, a lower calibration range of 500-10 $\mu \mathrm{g} \mathrm{L}^{-1}$ was also used. These solutions were prepared in quadruplicate, extracted and analyzed, as described above, generating a recovered analytical curve. The calibration line equations, correlation coefficients, limit of detection (LOD) and limit of quantification (LOQ) are displayed in Table S1 (SI section).

\section{Determination of estrogenic activity by YES assay}

The solutions used in the YES test were prepared according to Routledge and Sumpter, ${ }^{32}$ applying the 
adaptations reported by Bila et al. ${ }^{33}$ All reagents were purchased from Sigma-Aldrich (St. Louis, US). Glass flasks were rinsed with high-performance liquid chromatography (HPLC) absolute ethanol (Merck, Darmstadt, Germany) and pyrogen-free water $\left(<0.001\right.$ endotoxin $\left.\mathrm{mL}^{-1}\right)$ obtained from a Milli-Q Biocell system (Millipore, Mississauga, Canada). All procedures were performed in a laminar flow hood.

Analyzes were performed on the degradation experiment samples directly exposed to solar radiation in the HA solution. An $8 \mathrm{~mL}$ aliquot of these solutions was subjected to the previously described extraction process and resuspended in $4 \mathrm{~mL}$ of ethanol.

ATZ (1 $\left.\mathrm{mg} \mathrm{L}^{-1}\right)$, DEA $(250 \mu \mathrm{g} \mathrm{L}-1)$ and DIA $\left(150 \mu \mathrm{g} \mathrm{L}^{-1}\right)$ ethanol solutions were also subjected to the YES test, both alone and in conjunction with samples to verify potential synergistic effects.

Agonist and antagonist effects were evaluated in the samples obtained from the degradation tests. In the first case, agonist effects were determined using the YES assay. This recombinant Saccharomyces cerevisiae cell line contains the human estrogen receptor gene linked to a receptor gene encoding $\beta$-galactosidase. This enzyme is produced in estrogenic substances and metabolites of the chromogenic substrate chlorophenol red- $\beta$-D-galactopyranoside (CPRG, Sigma-Aldrich, St. Louis, USA). The initial compound is usually yellow and changes to a red product that can be measured by assessing its absorbance at $540 \mathrm{~nm}$. Thus, $\beta$-galactosidase expression can be quantified using a SPECTRAMAX M3 plate reader (Molecular Devices, San Jose, USA), which allows the determination of the concentrations of substances that result in estrogenic effects.

Briefly, the assay was performed as follows. The E2 (17ß-estradiol, Sigma-Aldrich, St. Louis, USA) standard solution and the samples were serially diluted in ethanol and $10 \mu \mathrm{L}$ (in duplicate) from each dilution was then transferred to a 96-well optically flat microtiter plate and allowed to evaporate to dryness. Then, $200 \mu \mathrm{L}$ of seeded yeast containing CPRG was added to the wells. The plates were then sealed with autoclave tape and shaken vigorously for 2 min (Digital Microplate Shaker, model MS3, Ika, Staufen, Germany). After incubation for $72 \mathrm{~h}$ at $30^{\circ} \mathrm{C}$, absorbances at $540 \mathrm{~nm}$ for color and $620 \mathrm{~nm}$ for turbidity were determined on a plate reader (SPECTRAMAX M3 plate reader (Molecular Devices, San Jose, USA). Ethanol and E2 (serial diluted) were used as blank solvent and positive controls, respectively. Antagonistic effects were determined the same way, but E2 was added to the samples to evaluate possible estradiol activity suppression.

The dose-response curves were plotted using the absorbance correction according to:
$\mathrm{A}_{\mathrm{ca}}=\mathrm{A}_{\mathrm{a} 540}-\left(\mathrm{A}_{\mathrm{a} 620}-\mathrm{A}_{\mathrm{b} 620}\right)$

where $\mathrm{A}_{\mathrm{ca}}$ is the corrected absorbance of the sample; $\mathrm{A}_{\mathrm{a} 540}$ is the sample absorbance at $540 \mathrm{~nm} ; \mathrm{A}_{\mathrm{ab} 20}$ is the sample absorbance at $620 \mathrm{~nm}$ and $\mathrm{A}_{\mathrm{b} 620}$ is the blank absorbance at $620 \mathrm{~nm}$.

Corrections were performed for each sample and the $17 \beta$-estradiol positive control. The dose-response curve was averaged for corrected duplicate absorbances as a function of sample concentration or positive control in each well on a logarithmic scale.

\section{Acute toxicity determination by a brine shrimp assay}

Artemia salina is a primitive aquatic arthropod that belongs to the Arthropoda phylum, Crustacea class and Artemiidae family. It is a very adaptable larva that can survive a wide range of salinities $\left(5-250 \mathrm{~g} \mathrm{~L}^{-1}\right)$ and temperatures $\left(6-35^{\circ} \mathrm{C}\right) \cdot{ }^{34}$ Artemia salina assays are widely used as this microcrustacean is easy to culture, low cost, commercially available as dry cysts and recommended by Brazilian standards. ${ }^{35}$ Their cysts may be conserved for long periods. Their life cycle begins with the outbreak of dormant cysts $(0.2-0.3 \mathrm{~mm})$. Once placed in saltwater and incubated at ca. $25{ }^{\circ} \mathrm{C}$, they hatch as nauplii $(0.45 \mathrm{~mm})$ over 24 to $48 \mathrm{~h}$ and are ready for use in ecotoxicity assessments. ${ }^{36,37}$

The Artemia salina toxicity test methodology was performed according to Persoone and Castritsi-Catharios, ${ }^{38}$ with modifications. Briefly, $150 \mathrm{mg}$ of Artemia salina cysts were incubated in $500 \mathrm{~mL}$ of seawater in a rectangular glass container and maintained at $25^{\circ} \mathrm{C}$ under a $20 \mathrm{~W}$ illumination for $48 \mathrm{~h}$. Then, 10 to 20 Artemia salina larvae were transferred to test tubes containing ATZ, DEA and DIA individually in seawater at 1, 5, 10, 25, 50 and $100 \mathrm{mg} \mathrm{L}^{-1}$. Seawater was collected from the municipality of Cabo Frio (22 $52^{\prime} 43^{\prime \prime} \mathrm{S}, 42^{\circ} 1$ ' $12^{\prime}$ 'W), Rio de Janeiro, and kept at $10^{\circ} \mathrm{C}$ in a polyethylene terephthalate bottle. Before use, the water was aerated for $1 \mathrm{~h}$. Larvae $(2 \mathrm{~mL})$ were transferred to test tubes containing $8 \mathrm{~mL}$ of pesticidecontaminated saline.

Assays were performed in quadruplicate with constant illumination $(20 \mathrm{~W})$ and controlled temperature $\left(25^{\circ} \mathrm{C}\right)$. The number of live Artemia larvae was determined after 24 and $48 \mathrm{~h}$. Quadruplicate controls were also performed using only seawater. After counting the live larvae, the mean effective concentrations $\left(\mathrm{EC}_{50}\right)$ of ATZ and its degradation products, DEA and DIA, which result in the death of $50 \%$ of exposed organisms, were determined. In this case, the effect was acute, as observed by the test organism lethality. 
Table 4. Possible ATZ degradation processes under the various investigated conditions

\begin{tabular}{|c|c|c|}
\hline Acronym & Description & Degradation process \\
\hline LPW & atrazine in aqueous solution directly exposed to solar radiation & hydrolysis and direct photolysis \\
\hline DPW & $\begin{array}{l}\text { atrazine in aqueous solution exposed to solar radiation covered with aluminum foil } \\
\qquad(\text { dark simulation })^{\mathrm{a}}\end{array}$ & hydrolysis \\
\hline LHA & atrazine in humic acid solution directly exposed to solar radiation & hydrolysis, direct and indirect photolysis \\
\hline DHA & $\begin{array}{l}\text { atrazine in humic acid solution exposed to solar radiation covered with aluminum } \\
\text { foil (dark simulation) })^{\mathrm{a}}\end{array}$ & hydrolysis \\
\hline LiRW & atrazine in river water in natura directly exposed to solar radiation & $\begin{array}{l}\text { hydrolysis, direct and indirect photolysis, and } \\
\text { biodegradation }\end{array}$ \\
\hline DiRW & $\begin{array}{l}\text { atrazine in river water in natura directly exposed to solar radiation covered with } \\
\text { aluminum foil (dark simulation) })^{\mathrm{a}}\end{array}$ & hydrolysis and biodegradation \\
\hline LaRW & atrazine in river water autoclaved directly exposed to solar radiation & hydrolysis, direct and indirect photolysis \\
\hline DaRW & $\begin{array}{l}\text { atrazine in river water autoclaved exposed directly to solar radiation covered with } \\
\text { aluminum foil (dark simulation) }\end{array}$ & hydrolysis \\
\hline
\end{tabular}

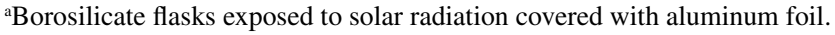

\section{Results and Discussion}

\section{ATZ photochemical degradation}

The ATZ transformation was assessed under natural condition simulations on tropical radiation in the summer and fall. Table 4 summarizes the possible degradation processes for ATZ evaluated in this study.

The atrazine degradation results for fall and summer are displayed in Figures 2 and 3 and Table 5.

The kinetic data shown in Table 5 were determined using a first-order model. Second- and zero-order models were also tested, but the first-order models were shown to be more appropriate for describing atrazine degradation kinetics. In general, they presented higher squared correlation coefficient $\left(\mathrm{r}^{2}\right)$ values and were
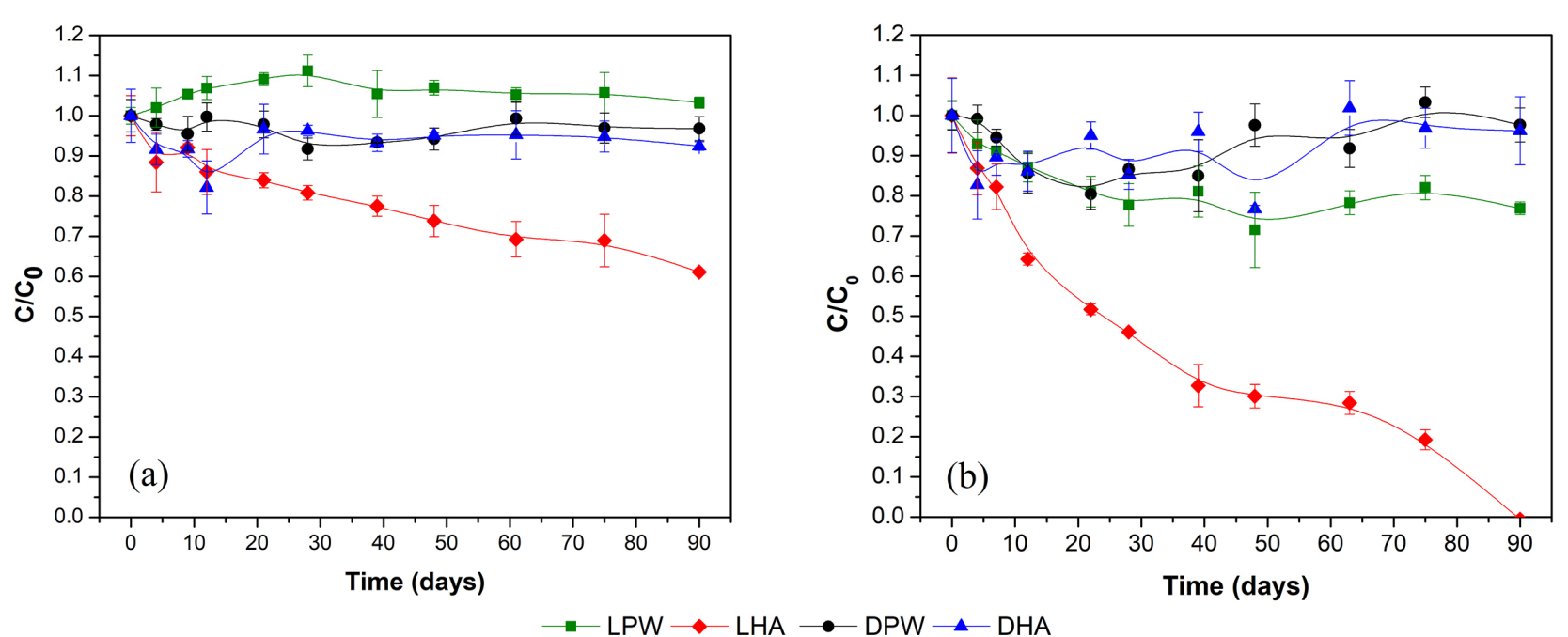

Figure 2. Atrazine degradation in aqueous solutions exposed to different conditions. LPW and DPW: atrazine in aqueous solution directly exposed to sunlight and covered with aluminum foil (dark simulation), respectively; LHA and DHA: atrazine in humic acid solution directly exposed to sunlight and covered with aluminum foil (dark simulation). (a) Fall; (b) summer. already described in previous works. ${ }^{16,25,39}$ These data were determined only for exposure directly to solar radiation, LHA, LiRW and LaRW. Due to the low degradation rates, it was not possible to determine the kinetics for the other conditions (LPW, DPW, DHA, DiRW and DaRW). For first-order kinetic degradation, the $\mathrm{C} / \mathrm{C}_{0}$ ratio decreases exponentially with time $\left([\mathrm{C}]=\left[\mathrm{C}_{0}\right] \mathrm{e}^{-\mathrm{kt}}\right)$ and the reagent/ pollutant half-life $(\ln 2 / \mathrm{k})$ is independent of its initial concentration. Thus, decreasing the concentration of atrazine in the solution during the degradation process does not reduce its half-life. ${ }^{40}$

More significant degradation was observed only when atrazine was directly exposed to solar radiation in the presence of HA or natural water. Thus, the indirect photolysis process had a crucial contribution to atrazine degradation than the other postulated processes. However, even in these 


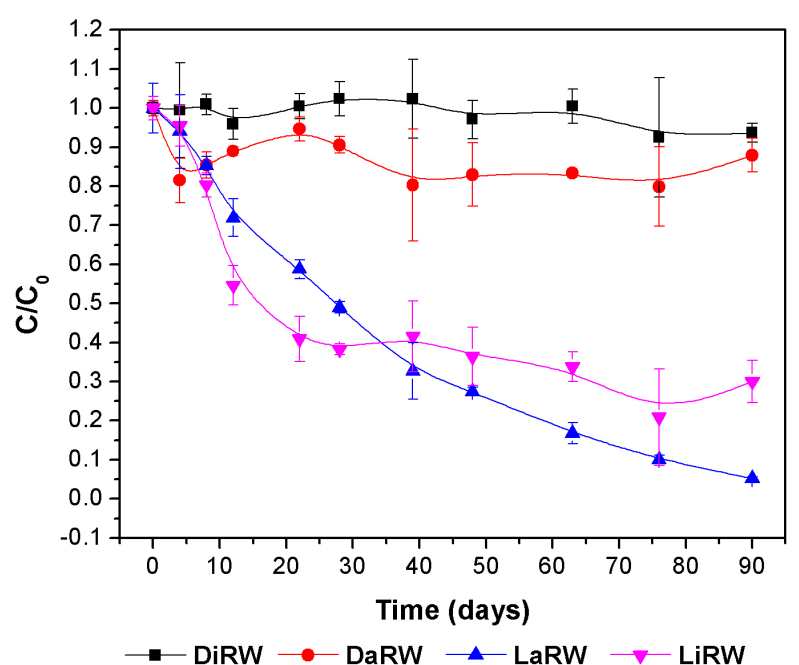

Figure 3. Atrazine degradation in river water exposed to different conditions in the summer. LaRW and DaRW: atrazine in river water autoclaved directly exposed to sunlight and covered with aluminum foil (dark simulation), respectively; LiRW and DiRW: atrazine in river water in natura directly exposed to sunlight and covered with aluminum foil (dark simulation).

conditions, the atrazine degradation approaches $100 \%$ $\left(\mathrm{C} / \mathrm{C}_{0}\right.$ ca. 0.0$)$ in the tropical summer after only 90 days of exposure. When the exposition was made in the fall, this value was less than $50 \%\left(\mathrm{C} / \mathrm{C}_{0}\right.$ ca. 0.5$)$ for LHA, revealing the atrazine persistence in the aquatic environment. ${ }^{16,25}$

These results are similar to those found by Lartiges and Garrigues ${ }^{16}$ and Navarro et al..$^{25}$ when studying the degradation of atrazine and three other triazines in river water, seawater and groundwater. The differences may be related to water composition and radiation between temperate and tropical environments. Lartiges and Garrigues $^{16}$ observed 59 days using non-filtered river water and attributed the higher conversion at HA in the samples, but dissolved organic carbon (DOC) or humic

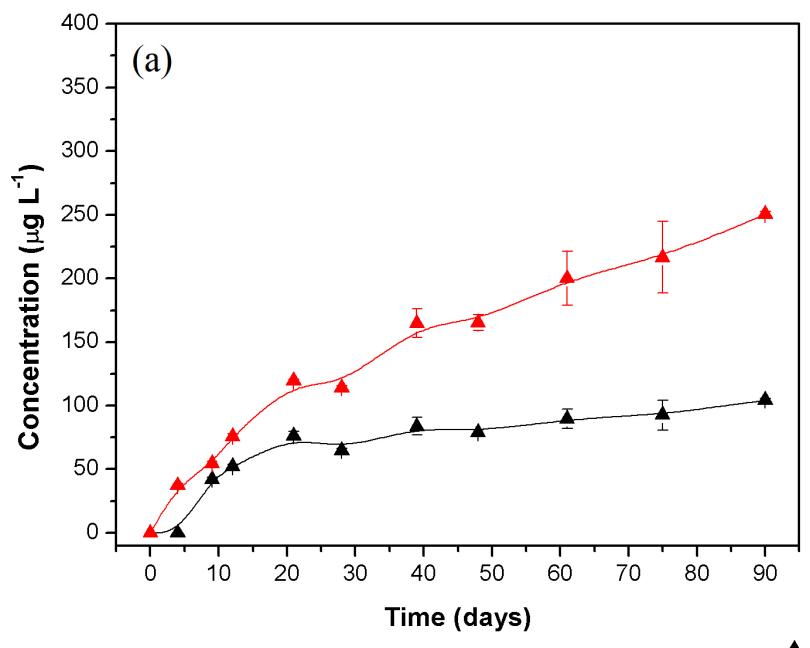

substance concentrations were not reported. In contrast, Navarro et al..$^{25}$ subjected the atrazine to natural solar radiation for $8 \mathrm{~h}$ a day for 127 days and evaluated their behavior in the dark. Atrazine degradation in river water was similar in the light and dark (56 and 53\%, respectively), indicating that radiation did not significantly influence the behavior of these pesticides in river water, in contrast to seawater and groundwater. Atrazine degradation in seawater under light was $69 \%$, while this value decreased to $37 \%$ in the dark. Atrazine degraded $57 \%$ under light and $30 \%$ in the dark in the groundwater, displaying higher persistence of the studied compounds in light and dark. Simultaneously, the degradation rates were higher in sea and river water. ${ }^{25}$

Other authors have also emphasized the influence of humic substance concentrations on atrazine degradation. Navarro et al. ${ }^{25}$ reported a higher DOC in the river water (11.3 $\left.\mathrm{mg} \mathrm{L}^{-1}\right)$ than the river water used in this work $\left(2.95 \mathrm{mg} \mathrm{L}^{-1}\right)$. Prosen and Zupančič-Kralj ${ }^{18}$ discussed hydrolysis catalyzed by HA in higher concentrations. The authors observed an increase in atrazine degradation using $500 \mathrm{mg} \mathrm{L}^{-1}$ of HA, both in light and dark conditions. Lin and $\mathrm{Chu}^{41}$ found that for HA up to $10 \mathrm{mg} \mathrm{L}^{-1}$, there is an increase in the photolysis rate of atrazine. In this work, the HA in the river water is not measured but the DOC was $2.95 \mathrm{mg} \mathrm{L}^{-1}$ and the experiments with HA solutions (LHA and DHA) were $6 \mathrm{mg}$ of HA L-1 (DOC $3.72 \mathrm{mg} \mathrm{L}^{-1}$ ).

Two ATZ degradation products were detected in the LAH matrix: DEA and DIA (Figure S2, SI section). Figure 4 shows the increased concentration of these products throughout the exposure period to solar radiation in experiment 1 (mostly fall, Figure $4 \mathrm{a}$ ) and experiment 2 (mostly summer, Figure 4b).

In both experiments, DEA was the most abundant intermediate. Similar results were observed by

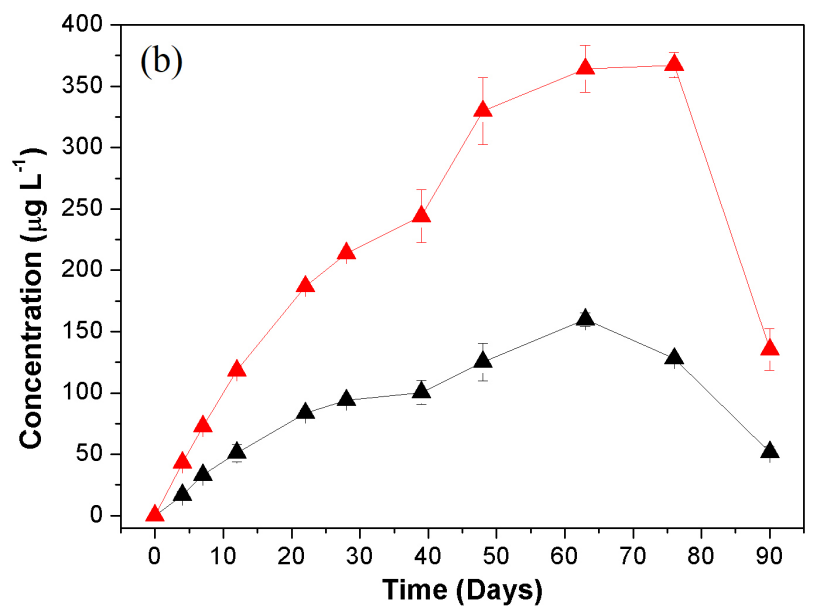

Figure 4. Metabolite formation during exposure to solar radiation in LAH: (a) experiment 1 (mostly fall); (b) experiment 2 (mostly summer). 
Table 5. Kinetic data determined for atrazine degradation under sunlight

\begin{tabular}{|c|c|c|c|c|c|}
\hline Experiment/exposure date and season & Acronym & Initial $\mathrm{pH}$ & $\mathrm{k}^{\mathrm{a}} /$ days $^{-1}$ & $\mathrm{t}_{1 / 2} \mathrm{~b}^{\mathrm{b}} /$ days & $\mathrm{r}^{2 \mathrm{a}}$ \\
\hline (1) $04 / 23 / 2015$ to $07 / 22 / 2015$ (mostly fall) & $\mathrm{LHA}^{\mathrm{c}}$ & 6.58 & $4.68 \times 10^{-3}$ & 148.1 & 0.951 \\
\hline (2) $01 / 05 / 2017$ to $04 / 05 / 2017$ (mostly summer) & $\mathrm{LHA}^{\mathrm{c}}$ & 7.32 & $2.85 \times 10^{-2}$ & 24.3 & 0.773 \\
\hline \multirow{2}{*}{ (3) $01 / 11 / 2018$ to $04 / 11 / 2018$ (mostly summer) } & $\mathrm{LaRW}^{\mathrm{d}}$ & 8.26 & $3.18 \times 10^{-2}$ & 21.8 & 0.999 \\
\hline & $\mathrm{LiRW}^{\mathrm{e}}$ & 7.31 & $1.43 \times 10^{-2}$ & 48.5 & 0.773 \\
\hline
\end{tabular}

${ }^{\mathrm{a}}$ Kinetic constant obtained by curve of $\ln [\mathrm{C}] /\left[\mathrm{C}_{0}\right]$ versus time, where the angular coefficient is $-\mathrm{k}$ and $\mathrm{r}^{2}$ is the squared correlation coefficient; ${ }^{\mathrm{b}}$ half-life determined from $\ln 2 / \mathrm{k}$; ${ }^{c} \mathrm{LHA}$ : atrazine in humic acid solution directly exposed to sunlight; ${ }^{\mathrm{L}}$ LaRW: atrazine in river water autoclaved directly exposed to sunlight; ${ }^{\mathrm{L}} \mathrm{LiRW}$ : atrazine in river water in natura directly exposed to sunlight.

Marchetti et al. ${ }^{42}$ and Vonberg et al..$^{43}$ The difference was between the amount of these compounds formed between the first and second experiments, which differ in radiation intensity (experiment 1: $142.8 \mathrm{~W} \mathrm{~m}^{-2}$; experiment 2 : $276.8 \mathrm{~W} \mathrm{~m}^{-2}$ ). These results show the influence of radiation on indirect photolysis processes in the formation of intermediates. However, although the maximum has reached a higher concentration in the experiment carried out in the summer, there is a drop in irradiation time, showing that the byproducts are decomposed during the exposition. The decrease of total atrazine was $40 \%$ in fall, and in summer, it reached $97 \%$.

\section{Estrogenic activity assessed by YES assay}

The dose-response curve of the $17 \beta$-estradiol standard used as a positive control of the YES assay is displayed in Figure 5.

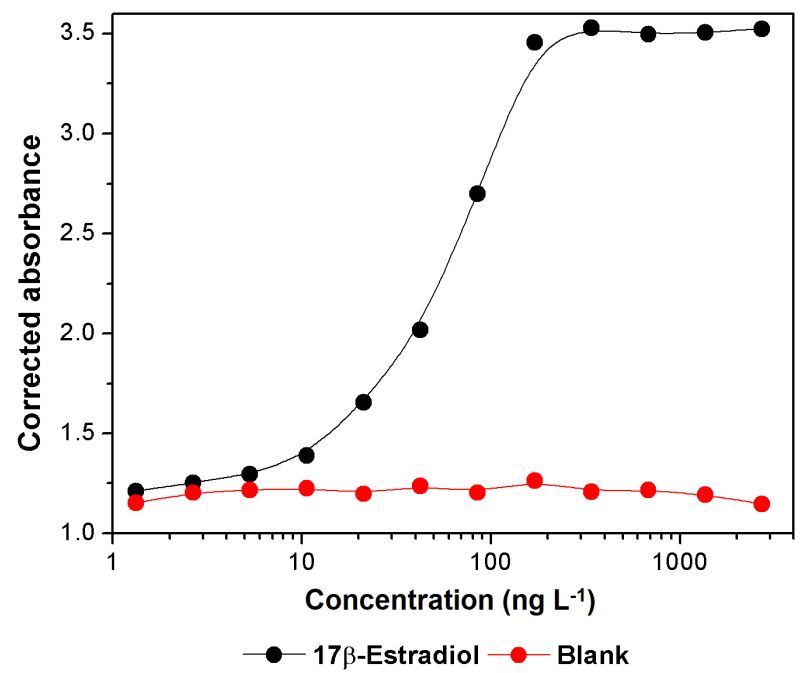

Figure 5. Standard dose-response curve of positive 17 $\beta$-estradiol control at a concentration range from $54.4 \mu \mathrm{g} \mathrm{L}^{-1}$ to $26.6 \mathrm{ng} \mathrm{L}^{-1}$ mother solution and $2.724 \mu \mathrm{g} \mathrm{L}^{-1}$ to $1.330 \mathrm{ng} \mathrm{L}^{-1}$ in each plate well.

The standard 17 $\beta$-estradiol positive control curve agrees with the values reported in the literature, ${ }^{32}$ confirming method validation. Although the dose-response curves of the samples were also determined, they did not present the same sigmoidal pattern as the $17 \beta$-estradiol curve, for both the agonist and antagonist effect assays (Figure 5), as no absorbances decreases at $620 \mathrm{~nm}$ were observed compared to the reference wells, indicating no yeast cell growth inhibition.

The plates containing the ATZ, DEA and DIA samples displayed no color change before and after the incubation period, indicating either low concentrations or a lack of estrogenic substances in the medium.

YES tests for atrazine were also performed by Pereira. ${ }^{44}$ However, the evaluations were carried out in samples that also underwent degradation processes by ozonation. Therefore, Pereira ${ }^{44}$ reported weak estrogen behavior and the substance responsible for this poor estrogenicity is not identified as different atrazine byproducts were present in the sample, including DEA and DIA.

Kolle et al. ${ }^{45}$ when performing estrogen and androgen agonist and antagonist effect studies, concluded that atrazine displays none of these effects or weak estrogen agonist effect only. Hayes et al. ${ }^{11}$ concluded that atrazine is a potent endocrine disruptor when analyzing its long-term effects on adult amphibians. Males exposed to $2.5 \mathrm{mg} \mathrm{g}^{-1}$ of this substance were demasculinized (chemically castrated) and completely feminized as adults. Decreased spermatogenesis and fertility were also observed. ${ }^{11}$

Finally, atrazine is well known as an endocrine disruptor ${ }^{11,46}$ and some authors ${ }^{47}$ have claimed that it displays a weak estrogen effect, as it exerts more considerable influence on androgen inhibition. In this work, we showed no estrogen effect in the concentrations studied using the YES tests.

\section{Acute Artemia salina toxicity assays}

The results regarding Artemia salina larvae mortality after exposure to different ATZ, DEA, and DAY concentrations for $24 \mathrm{~h}$ are displayed in Figure 6.

Increased Artemia salina larvae mortality was observed with increasing ATZ-contaminated seawater samples and 


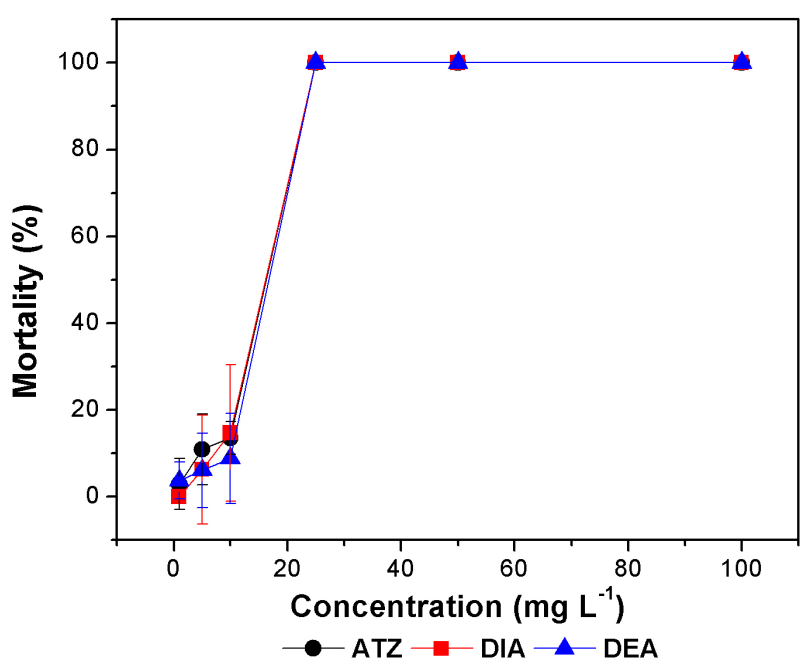

Figure 6. Relationship between Artemia salina larvae mortality and increasing ATZ, DEA and DIA concentrations.

samples contaminated with DEA and DIA degradation products. The $\mathrm{EC}_{50}$ (Table 6) was determined based on these data for ATZ and its degradation products.

Table 6. $\mathrm{EC}_{50}$ values determined after 24 and $48 \mathrm{~h}$ for ATZ, DEA and DIA

\begin{tabular}{|c|c|c|}
\hline \multirow{2}{*}{$\begin{array}{l}\text { Pesticide or } \\
\text { intermediate }\end{array}$} & \multicolumn{2}{|c|}{$\mathrm{EC}_{50}($ standard deviation estimate $) /\left(\mathrm{mg} \mathrm{L}^{-1}\right)$} \\
\hline & $24 \mathrm{~h}$ & $48 \mathrm{~h}$ \\
\hline$\overline{\text { ATZ }}$ & $13.54(1.09)$ & - \\
\hline DEA & $13.05(1.36)$ & $12.95(1.12)$ \\
\hline DIA & $12.74(1.22)$ & $12.66(1.14)$ \\
\hline
\end{tabular}

$\mathrm{EC}_{50}$ : mean effective concentration that kill $50 \%$ of Artemia salina; ATZ: atrazine; DEA: desethylatrazine; DIA: deisopropylatrazine.

Artemia salina larvae were determined after 24 and $48 \mathrm{~h}$ and no difference in the $\mathrm{EC}_{50}$ values for both periods was noted. Thus, the data obtained after $24 \mathrm{~h}$ of incubation were used. The findings indicate that DEA and DIA toxicity is very close to the toxicity of the original molecule. Therefore, although atrazine degrades in the aquatic environment, it also releases degradation products displaying similar toxicity, which may cause harmful and unknown effects to aquatic organisms.

The Artemia salina toxicity test was not performed for samples used in the atrazine degradation studies under solar radiation. In these degradation studies, the initial ATZ concentration was ca. $1 \mathrm{mg} \mathrm{L}^{-1}$, i.e., non-toxic to Artemia salina.

\section{Conclusions}

The results of this study contributed to understanding and estimating the phototransformation of atrazine in tropical environments and intermediate production. ATZ degradation assays confirm that indirect photolysis is the mechanism responsible for pesticide degradation in summer and fall, triggered by humic acids dissolved in the matrix. In the summer, the same kinetics are observed but the halftime of this compound is approximately six-fold lower than in fall, and direct photolysis is observed in ultra-pure water. The temperature variation between fall and summer was not prominent due to tropical conditions and it did not follow in the hydrolysis process.

The ATZ degradation byproducts detected in these experiments were DEA and DIA. Higher production of these compounds was observed in the summer and decay of concentration during exposure was followed, in contrast to the fall experiment. Other byproducts were not detected with the analytical methodology applied.

The Artemia salina test determined the ATZ, AED and DIA toxicities and similarity for the $\mathrm{EC}_{50}$ values was verified. The $\mathrm{EC}_{50}$ values are high, so no issues regarding the environmental concentration of these compounds are noted. DEA and DIA formation was on the order of the $\mu \mathrm{g} \mathrm{L^{-1 }}$ range, indicating no increased system toxicity. The YES assay demonstrated that ATZ and its degradation products do not display estrogenic or antiestrogenic activity at the assessed concentrations.

\section{Supplementary Information}

Supplementary information contains a photo of the experimental set up to perform the atrazine abiotic degradation test under irradiation (Figure S1) and the chromatogram and spectra of byproducts (Figure S2); and Table S1 shows the calibration line equations, correlation coefficients, LOD and LOQ for ATZ, DIA and DEA in ultrapure water, water with HA and natural water (from river), and it is available free of charge at http://jbcs.sbq.org.br as a PDF file.

\section{Acknowledgments}

The authors are thankful to Instituto Nacional de Ciências e Tecnologia Analíticas Avançadas (INCTAACNPq, 573894/2008-6 and 465768/2014-8), CAPES and CNPq (303285/2019-2).

\section{Author Contributions}

Polyana S. Barcellos, Thiago M. R. Araújo and Maria C. Canela conceived, designed the experiment and writing-original draft preparation; Polyana S. Barcellos, Giselle Gomes and Daniele M. Bila performed the YES test; Polyana S. Barcellos, Thiago M. R. Araújo and Giselle Gomes analyzed the data; Polyana S. Barcellos, 
Thiago M. R. Araújo and Maria C. Canela participated in writingreview and editing; Maria C. Canela and Daniele M. Bila provided the financial support.

\section{References}

1. World Health Organization (WHO); Household Air Pollution Data, https://www.who.int/data/gho/data/themes/air-pollution/ household-air-pollution, accessed in February 2022.

2. Food and Agriculture Organization (FAO); Pesticides Use, Pesticides Trade and Pesticides Indicators, https://www.fao. org/3/cb6034en/cb6034en.pdf, accessed on January 04, 2022.

3. Brovini, E. M.; de Deus, B. C. T.; Vilas-Boas, J. A.; Quadra, G. R.; Carvalho, L.; Mendonça, R. F.; Pereira, R. O.; Cardoso, S. J.; Sci. Total Environ. 2021, 771, 144754.

4. Pimentel, D.; J. Agric. Environ. Ethics 1995, 8, 17.

5. U.S. Environmental Protection Agency (EPA), Atrazine, https:// www.epa.gov/ingredients-used-pesticide-products/atrazine, accessed on January 4, 2022.

6. Instituto Brasileiro de Geografia e Estatística (IBGE); Sistema IBGE de Recuperação Automática - SIDRA, https://sidra.ibge. gov.br/tabela/774, accessed in February 2022.

7. Barizon, R. R. M.; Figueiredo, R. O.; Dutra, D. R. C. S.; Regitano, J. B.; Ferracini, V. L.; J. Environ. Sci. Health, Part B 2020, 55, 283.

8. Portal, T. P.; Pedlowski, M. A.; de Almeida, C. M. S.; Canela, M. C.; Heliyon 2019, 5, e01295.

9. Machado, K. C.; Grassi, M. T.; Vidal, C.; Pescara, I. C.; Jardim, W. F.; Fernandes, A. N.; Sodré, F. F.; Almeida, F. V.; Santana, J. S.; Canela, M. C.; Nunes, C. R. O.; Bichinho, K. M.; Severo, F. J. R.; Sci. Total Environ. 2016, 572, 138.

10. Cerdeira, A.; Santos, N.; Pessoa, M.; Gomes, M.; Lanchote, V.; J. Environ. Sci. Health, Part B 2005, 40, 159.

11. Hayes, T. B.; Khoury, V.; Narayan, A.; Nazir, M.; Park, A.; Brown, T.; Adame, L.; Chan, E.; Buchholz, D.; Stueve, T.; Gallipeau, S.; Proc. Natl. Acad. Sci. U. S. A. 2010, 107, 4612.

12. Cragin, L.A.; Kesner, J. S.; Bachand, A. M.; Barr, D. B.; Meadows, J. W.; Krieg, E. F.; Reif, J. S.; Environ. Res. 2011, 111, 1293.

13. Swan, S. H.; Kruse, R. L.; Liu, F.; Barr, D. B.; Drobnis, E. Z.; Redmon, J. B.; Wang, C.; Brazil, C.; Overstreet, J. W.; Environ. Health Perspect. 2003, 111, 1478.

14. Mudhoo, A.; Garg, V. K.; Pedosphere 2011, 21, 11.

15. Wang, Z.; Ouyang, W.; Tysklind, M.; Lin, C.; Wang, B.; Environ. Pollut. 2021, 283, 117072.

16. Lartiges, S. B.; Garrigues, P. P.; Environ. Sci. Technol. 1995, 29, 1246.

17. Stevenson, F. J.; Humus Chemistry - Genesis, Composition, Reactions, $1^{\text {st }}$ ed.; Wiley: New York, USA, 1982.

18. Prosen, H.; Zupančič-Kralj, L.; Environ. Pollut. 2005, 133, 517.

19. Mansour, M.; Feicht, E. A.; Behechti, A.; Schramm, K.-W.; Kettrup, A.; Chemosphere 1999, 39, 575.
20. Wolfe, N. L.; Mingelgrin, U.; Miller, G. C. In Pesticides in the Soil Environment: Processes, Impacts and Modeling, $1^{\text {st }}$ ed.; Cheng, H. H., ed.; Soil Science Society of America: Madison, USA, 1990, ch. 5 .

21. Burrows, H. D.; Canle, L. M.; Santaballa, J. A.; Steenken, S.; J. Photochem. Photobiol., B 2002, 67, 71.

22. Konstantinou, I. K.; Zarkadis, A. K.; Albanis, T. A.; J. Environ. Qual. 2001, 30, 121.

23. Araújo, T. M.; Campos, M. N. N.; Canela, M. C.; Int. J. Environ. Anal. Chem. 2007, 87, 937.

24. Araújo, T. M. R.; Canela, M. C.; Miranda, P. C. M. L.; J. Environ. Sci. Health, Part B 2013, 48, 251.

25. Navarro, S.; Vela, N.; Giménez, M. J.; Navarro, G.; Sci. Total Environ. 2004, 329, 87.

26. Erickson, L. E.; Lee, K. H.; Sumner, D. D.; Crit. Rev. Environ. Control 1989, 19, 1.

27. Furman, O. S.; Yu, M.; Teel, A. L.; Watts, R. J.; Chemosphere 2013, 93, 1734.

28. Baranda, A. B.; Barranco, A.; de Marañón, I. M.; Water Res. 2012, 46, 669.

29. Pacheco, F. S.; Miranda, M.; Pezzi, L. P.; Assireu, A.; Marinho, M. M.; Malafaia, M.; Reis, A.; Sales, M.; Correia, G.; Domingos, P.; Iwama, A.; Rudorff, C.; Oliva, P.; Ometto, J. P.; Limnol. Oceanogr. 2017, 62, S131.

30. US EPA, CRF40, https://www.ecfr.gov/current/title-40/ chapter-I/subchapter-R/part-795/subpart-B/, accessed on January 4, 2022.

31. ASTM D1209-00: Standard Test Method for Color of Clear Liquids (Platinum-Cobalt Scale), https://www.astm.org/d120905r19.html, accessed on January 4, 2022.

32. Routledge, E. J.; Sumpter, J. P.; Environ. Toxicol. Chem. 1996, $15,241$.

33. Bila, D.; Montalvão, A. F.; Azevedo, D. A.; Dezotti, M.; Chemosphere 2007, 69, 736.

34. Cruzeiro, C.; Rocha, E.; Pardal, M. Â.; Rocha, M. J.; Mar. Pollut. Bull. 2016, 103, 240.

35. Companhia Ambiental do Estado de São Paulo (CETESB); Água do Mar - Teste de Toxicidade Aguda com Artemia: Método de Ensaio, https://www.cetesb.sp.gov. br/normas/desativadas/L5.021_\%C3\%81gua\%20do\%20 mar\%20\%E2\%80\%93\%20teste\%20de\%20toxicidade\% 20 aguda $\% 20$ com $\% 20$ artemia.pdf?_ga $=2.240756160$. 2127318542.1641495532-358361708.1641495532, accessed on January 4, 2022.

36. Nunes, B. S.; Carvalho, F. D.; Guilhermino, L. M.; Van Stappen, G.; Environ. Pollut. 2006, 144, 453.

37. Shaw, I. C.; Chadwick, J.; Principles of Environmental Toxicology, $1^{\text {st }}$ ed.; CRC Press: Philadelphia, USA, 1998.

38. Persoone, G.; Castritsi-Catharios, J.; Water Res. 1989, $23,893$. 39. Li, Y.; Cakmak, S.; Zhu, J.; Environ. Int. 2019, 126, 134.

40. Atkins, P.; Paula, J.; Physical Chemistry: Thermodynamics, 
Structure, and Change, $10^{\text {th }}$ ed.; W. H. Freeman and Company: New York, USA, 2014.

41. Lin, K. Y.; Chu, W.; J. Hazard. Mater. 2011, 192, 1260.

42. Marchetti, G.; Minella, M.; Maurino, V.; Minero, C.; Vione, D.; Water Res. 2013, 47, 6211.

43. Vonberg, D.; Vanderborght, J.; Cremer, N.; Pütz, T.; Herbst, M.; Vereecken, H.; Water Res. 2014, 50, 294.

44. Pereira, S. S.: Degradação da Atrazina pelo Processo UV/ $\mathrm{H}_{2} \mathrm{O}_{2}$ e Ozônio, Identificação dos Intermediários e Avaliação da Atividade Estrogênica; PhD Thesis, Universidade Federal do Rio de Janeiro, Rio de Janeiro, Brazil, 2011, available at http://portal.peq.coppe.ufrj.br/index.php/teses-dedoutorado/2011/107-degradacao-da-atrazina-pelo-processo- uvh2o2-e-ozonio-identificacao-dos-intermediarios-e-avaliacaoda-atividade-estrogenica/file, accessed on January 4, 2022.

45. Kolle, S. N.; Kamp, H. G.; Huener, H.-A.; Knickel, J.; Verlohner, A.; Woitkowiak, C.; Landsiedel, R.; van Ravenzwaay, B.; Toxicol. In Vitro 2010, 24, 2030.

46. Solano, M.; Montagner, C. C.; Vaccari, C.; Jardim, W. F.; Anselmo-Franci, J. A.; Carolino, R. O.; Luvizutto, J. F.; Umbuzeiro, G. A.; de Camargo, J. L.; Endocr. Disruptors 2015, 3, e983384.

47. Cooper, R. L.; Toxicol. Sci. 2000, 53, 297.

Submitted: October 31, 2021

Published online: February 15, 2022 